contributors have now largely displaced the original enunciation of the thesis, and that perhaps there is no one key to all mythologies as George Eliot's Mr. Casaubon would have it.

Nancy Christie

University of Western Ontario

Christopher Dummitt and Michael Dawson, eds., Contesting Clio's Craft: New Directions and Debates in Canadian History (London: Institute for the Study of the Americas, 2009).

As one of only a few essay collections since the publication of Carl Berger's Contemporary Approaches to Canadian History (1987) to claim to bring together "new" directions and debates in Canadian history, this volume marks an important milestone in Clio's craft. Berger concluded The Writing of Canadian History (1986) with the warning that Clio has "an alarming habit" of devouring those who follow her charms (320). Although young historians may well build upon the work of their predecessors, he implies, they are reluctant to admit doing so, preferring to emphasize their break with the tired approaches of their deluded mentors. It is instructive, then, to reflect on what a new generation of historians understands as cannibalism.

Unlike Berger's volume, which reprinted review articles on "the new history" in such sub-fields as ethnic, regional, women's, and working class history, this collection of essays emerged from a single conference, convened at the University of London in 2007. Those invited to present papers were junior scholars identified as charting new directions in theory and methodology. In addition to the editors, the essayists published in this volume include Michel Ducharme, Catherine Gidney, Stephen High, Adele Perry, Katie Pickles, and Andrew Smith. Instead of offering overviews of emerging sub-fields, the articles, we are told by the editors in the introduction, are meant to encourage debates that move beyond dated discussions about the failure of Canadians to know their own history; the role of social history in undermining the national narrative; and the nature of historical knowledge and claims to truth. While few academic historians would disagree with the need for more substantive debates on the form, content, and import of Canadian history, it is unclear from most of these essays what needs to be debated. The trends in historical inquiry promoted here - transnational, comparative, post-colonial, public/oral, narrative, and Atlantic world — to amend practices of earlier unworthies are timely suggestions and unlikely to generate much debate. Surely, such approaches co-exist comfortably with national and social understandings of the past, neither of which can or should be abandoned. Although the editors suggest that there are divisions among the authors of this volume on whether the attempt to write a 
more inclusive Canadian history is now intellectually bankrupt (Dummitt) or is a promise yet to be achieved (Perry), such a debate will not cause most historians many sleepless nights.

Having just retired after forty years of teaching Canadian history/historiography, I am, perhaps, just an old grump and I would be churlish not to admit that I actually like this book and would use it as a text if I were forced under pain of death to return to the classroom. The articles are accessibly written, they raise useful questions for our current generation of graduate students, and several - in particular, Magda Fahrni's exploration of the place of Quebec in Canadian historical writing, Stephen High's use of oral history as a vehicle for interrogating authority in historical practice, and Michael Dawson and Catherine Gidney's questioning of periodization in English Canada's twentieth century are genuine contributions to the Canadian historiographical canon. What I most miss here (and it suggests that I have lived too long) are the progressive politics that inspired me and many of the other authors who contributed to Berger's anthology (E.R. Forbes, Gerald Friesen, Bryan Palmer, Roberto Perin, for example). No doubt, it is timely to question an inclusive approach to the study of Canada, to lay claim to the positive legacy of British and other imperialisms, or to situate the study of Canada in a transnational post-colonial framework, but I am reluctant to relinquish truth claims to past oppressions of empires, near or far, or to bow to a research agenda that dilutes the focus on the specific nationstate, which still has the capacity to exert influence for good or ill. So, I will keep my black arm band - Andrew Smith's reference to Geoffrey Blainey's comment on critical approaches to Australia's past (75) - indeed, I will double its width in the current political climate.

The editors suggest that Ian MacKay's article on the "The Liberal Order Framework" is the kind of scholarship that might generate worthy academic discussion and it is to be hoped that another conference will be held in which historians, new and old, can move beyond intergenerational devourings to further explorations of the daunting historiographical challenges that face us in the twenty-first century.

Margaret Conrad University of New Brunswick

\section{Place and Practice in Canadian Nursing History, eds. Jayne Elliott, Meryn Stuart and Cynthia Toman (Vancouver: UBC Press, 2008).}

The first Hannah Conference on Canadian Nursing History held in Ottawa in June 2005 occurred amidst many 'firsts' in nursing history. These included the launch of the Nursing History Research Unit at the School of Nursing (University of Ottawa), with funding from Associated Medical Services, Inc., and 